Relations industrielles

Industrial Relations

\title{
Accréditation syndicale - « Domination " d'un syndicat par un employeur - Demande conjointe de deux syndicats pour former la majorité dans une unité de négociation, selon le Code du Travail.
}

Volume 20, numéro 2, 1965

URI : https://id.erudit.org/iderudit/027569ar

DOI : https://doi.org/10.7202/027569ar

\section{Aller au sommaire du numéro}

\section{Éditeur(s)}

Département des relations industrielles de l'Université Laval

\section{ISSN}

0034-379X (imprimé)

1703-8138 (numérique)

\section{Découvrir la revue}

\section{Citer cet article}

(1965). Accréditation syndicale - « Domination » d'un syndicat par un employeur - Demande conjointe de deux syndicats pour former la majorité dans une unité de négociation, selon le Code du Travail. Relations industrielles / Industrial Relations, 20(2), 372-391. https://doi.org/10.7202/027569ar

\section{Résumé de l'article}

La Commission des relations du travail décide que le caractère de « domination » d'un syndicat par l'employeur, tel que prohibé par l'article 11 du Code du Travail, doit être apprécié par la Commission selon « la balance des probabilités ", qui est la règle en droit civil. Une preuve circonstancielle, c'est-à-dire fondée sur des présomptions de faits, est suffisante pour décider " selon la balance des probabilités " qu'un syndicat est dominé par l'employeur.

La Commission décide aussi que deux associations peuvent s'entendre pour former la majorité requise pour l'obtention d'une accréditation syndicale dans une unité de négociation donnée, et ce, même si le code du Travail ne reproduit pas le deuxième paragraphe de l'article 4 de l'ancienne loi des relations ouvrières de Québec. ${ }^{1}$

1 L'Union des employés de MacFariane-Lefaivre Mfg. Ltd (Division Labelle) et l'Union des Ouvriers du cuir de Montréal, Local L-102, l'Union des Tailleurs en Chaussures, 118 LF, Locaux de l'Amalgamated Meat Cutters and Butcher Workmen of N.A. (AFL-CIO-CTC) les deux locaux conjointement, et Boucher et Lefaivre Ltd, la Commission des Relations du Travail; Dossier No. 8471-1-2-3, R-748A (1962) et R-34 (1964), Montréal, le 18 janvier 1965, Juge A.B. Gold, J.M.C.
Tous droits réservés (C) Département des relations industrielles de l'Université Laval, 1965
Ce document est protégé par la loi sur le droit d'auteur. L'utilisation des services d’Érudit (y compris la reproduction) est assujettie à sa politique d'utilisation que vous pouvez consulter en ligne.

https://apropos.erudit.org/fr/usagers/politique-dutilisation/ 


\section{JURISPRUDENCE DU TRAVAIL}

\section{ACCRÉDITATIION SYNDICALE - «Domination " d'un syndicat par un} employeur - Demande conjointe de deux syndicats pour former la majorité dans une unité de négociation, selon le Code du Travail.

La Commission des relations du travail décide que le caractère de "domination» d'un syndicat par l'employeur, tel que prohibé par l'article 11 du Code du Travail, doit être apprécié par la Commission selon a la balance des probabilités », qui est la règle en droit civil. Une preuve circonstancielle, c'est-à-dire fondée sur des présomptions de faits, est suffisante pour décider "selon la balance des probabilités qu'un syndicat est dominé par l'employeur.

La Commission décide aussi que deux associations peuvent s'entendre pour former la majorité requise pour l'obtention d'une accréditation syndicale dans une unité de négociation donnée, et ce, même si le Code du Travail ne reproduit pas le deuxième paragraphe de l'article 4 de l'ancienne loi des relations ouvrières de Québec. ${ }^{1}$

\section{LE CARACTERE DE «DOMINATION *}

The issue first arose with an application by the Cutters' Union (filed on October 29th, 1962) for certification as bargaining agent for "tous les tailleurs de dessus et de doublure à la main et à la machine " in the employ of Boucher $\mathcal{G}$ Lefoivre at its Papineau plant. The application was opposed by the Company on the ground, inter alia, that the bargaining unit was inappropriate. Shortly thereafter, (on November 13th, 1962) while the application of the Cutters' Union was being processed, the Association applief to be certified as bargaining agent for "tous les employés travaillant à la fabrication de la chaussure à la main ou à la machine $»$ in the said plant.

The Cutters' Union opposed this application chiefly on the ground that the Association was employer dominated, and not a bona fide association within the meoning of the Act. The Company did not oppose the Association's demand.

We made our statutory inquiry in the usual way regarding both applications, and then directed that a hearing be held to deal with the question, among others, whether the cutters constitute an appropriate group for bargaining purposes in the circumstances of the case.

1 L'Union des employés de MacFarlane-Lefaivre Mfg. Ltd (Division Labelle) et I'Union des Ouvriers du cuir de Montréal, Local L-102, I'Union des Tailleurs en Chaussures, $118 \mathrm{LF}$, Locaux de I'Amalgamated Meat Cutters and Butcher Workmen of N.A. (AFL(IO-CTC) les deux locaux conjointement, et Boucher et Lefaivre Ltd, lo Commission des Relations du Travail; Dossier No. 8471-1-2-3, R-748A (1962) et R-34 (1964) Montréal, le 18 janvier 1965, Juge A.B. Gold, J.M.C. 
Public hearings were held on this issue on March 26th, December 5th, December 6th and December 9th, 1963, and as our inquiry wos not then completed, the case was put over to a later date.

On Jonuary 17th, 1964, while the matter was still pending, and awoiting its turn on the roll for further hearing, the Amalgamated applied for certification as the bargaining ogent for «les employés de la production de la chaussure payés à l'heure et à la pièce » in the employ of the Company at the said Papineau plant. At the same time, the Cutters' Union discontinued its first demand to be certified as bargaining agent for the cutters done.

The Association and the Company both objected to the reception of the Amalgamated's application, and to the acceptance by the Board of the Cutters' Union discontinuance of its original demand, and we heard the parties on these preliminary questions at a hearing held on February 6th, 1964.

On June 5th, 1964, we dismissed the objections raised by the Association and the Company, the whole as appears from our decision of record herein, and reference to which is mode os if the same were herein set out of length.

This left us with the two contending applications concerning the production forces, to which we heve already referred, that of the Association filed on November 13th, 1962, and that of the Amalgamated, filed on January 17th, 1964. These are the proceedings which are the subject of the present decision.

We made our statutory inquiry as required, and then directed that a hearing be held. The parties appeared before us with counsel and their witnesses on June 21st, June 23rd, June 25th, September 28th, September 29th and September 30th, 1964, and were heard. We have taken time to consider the matter.

The record clearly indicates that both associations enjoy the representative character required for certification. Were there no other matters in issue we would have ordered a vote under Section 8 of the Act, or the latter portion of Section 25 of the Code, both of which provide for this remedy where " it appears that the said employees are members of more than one association in sufficient numbers to affect the decision $\mathrm{n}$. This, however, was not to be, for as we have seen, the Amalgamated opposed the demand of the Association on the ground that it is employer dominated, and hence not an association bona fide within the meaning of our law. It is this question which is principally in issue here, and most of the evidence made before us deals with this aspect of the case.

It remain only to say that the issue of employer domination is one of public order, and may be dealt with in our inquiry, proprio motu. It is to this question that we now direct our attention.

It is convenient to set out at this point the material provisions of law under which the issues arise. Because, as we have seen, the applications in this case were filed under the Act, we turn first to it. We begin with domination; this is dealt with in the Act by the following Sections :

« 20. No employer, nor person acting for an employer or an association of employers, shali in any manner seek to dominate or hinder the formation or the activities of any association of employees. 
44. Any person who fails to comply with any obligation or prohibition imposed by this act or by a regulation or decision of the Board is guilty of an offence and liable, unless another penalty is applicable, to a fine of not less than one hundred dollars nor more than one thousand dollars for each day or portion of a day during which the offence continues

46. The following shall be a party to an offence and liable to the penalty provided in the same manner as the person committing the offence; any person who aids or abets the commission thereof and, when the offence is committed by a corporation or an association, every director, administrator, manager or officer shall be guilty of the offence who, in any manner, approves of the act which constitutes the offence or acquiesces therein.

47. If severol persons conspire to commit an offence, each of them shall be guilty of each offence committed by any of them in the carrying out of their common intention.

48. The penalties contemplated by this act shall be imposed upon summary proceeding pursuant to the Quebec Summary Convictions Act (chap. 29).

Part II of the said act shall apply to such proceedings.

49. Any penal prosecution under this act may be taken by the Board, or by any interested party with the written authorization of the Board or the consent of the Attorney-General.

50. If it be (sic - should read proven) provided to the Board that an association has participated in an offence against section 20, the Board may, without prejudice to any other penalty, decree the dissolution of such association after giving it an opportunity to be heard and to produce any evidence tending to exculpate it.

In the case of a professional syndicate, an authentic copy of the decision shall be transmitted to the Provincial Secretary who shall give notice thereof in the Quebec Official Gazette.

Furthermore, By-Low No. I (enacted pursuant to the Act) contains the following Section, which applies, namely:

«2. For the purpose of determining the character of good faith of an association, the following conditions shall be complied with:

c) The association shall comply with the conditions set forth in paragraphe " $d$ » of section 2 of the Act;

d) The Board shall take into considerction the observance of sections 20, $21,22,24$ and 25 of the Act.

Domination is dealt with in the Code under Sections 11, 125, and 128 to 132 (inclusive). Sections 128 to 132 , (inclusive) are verbatim reproductions of Sections 46 to 50 (inclusive) of the Act, and need not be repeated here.

Section 11 of the Code enlarges upon Section 20 of the Act, but essentially the two provisions are the same. Section 125 of the Code is a specific section which creates an offence for infringement of Sections 11, 12 and 13 of the Code, replacing in part Section 44 of the Act, the general provisions of which are retained (with some modification) as Section 126 of the Code. For our purposes, it is sufficient to examine in detail Sections 11 and 125 of the Code, which read as follows: 
« 11. No employer, or person acting for an employer or an association of employers, shall in any manner seek to dominate, hinder or finance the formation or the activities of any association of employees, or to participate therein.

«No association of employees, or person acting on behalf of any such organization, shall belong to an association of employers or seek to dominate, hinder or finance the formation or activities of any such association, or to participate therein.

125. Any person who infringes any provision of section 11,12 or 13 , is guilty of an offence and liable to a fine of one hundred to one thousand dollars for each day or portion of a day during which such offence continues.

It is sufficient to read Section 20 of the Act and Section 11 of the Code to see their basic similarity. While Section 11, by the addition of the terms « finance 》, and «participate $»$, appears to enlarge upon the provisions of Section 20 of the Act, in fact, the new legislation is merely a recognition and clarification of the judicial interpretation placed upon the old enactment by our prior practice and jurisprudence. It remains only to state at this point that under the Act « association » is defined as follows:

" 2. - In this act and in its application, unless the context requires otherwise, the following words and expressions have the meaning hereinafter given to them:

d) "Association » includes a professional syndicote, a union of such syndicates, a group of employees or of employers, bona fide, having cs object the regulation of relations between employers and employees and the study, defence and development of the economic, social and moral interests of its members, with respect for law and authority; 》

Under the Code « association of employees $»$ is defined in the following terms:

a 1 . In this code, unless the context requires otherwise, the following expressions mean :

a. "association of employees " - a group of employees constituted as a professional syndicate, union, brotherhood or otherwise, having as its objects the study, safeguarding and development of the economic, social and educational interests of its members and particularly the negotiation and application of collective agreements; 》

The new definition of a association of employees 》 in the Code is an improvement in language, but not a change or modification in the basic object or purposes of the original enactment. The new section in the Code leaves us with a definition that is perhaps more elegant and more precise but essentially it is the same definition that we find in the Act. The deletion of the terms «bona fide ", and " with respect for law and authority *, is merely a pruning of useless verbiage - it is nothing more nor less than literary surgery. Surely no one will suggest that by eliminating these terms in the definition of \& association * in the Code, it was the legislative intent to direct us to certify an association which is in bad faith and which does not respect law and authority. We have no doubt that under the Code, as under the Act, an association must have as its honest purpose and object the protection and the defence of the interests of its members, and must pursue these objects in good faith and with respect for law and authority; otherwise it is simply not an association within the meaning of our law.

Hoving come to this conclusion, it is unnecessary to decide what is in the present instance the purely academic question whether Section 136 of the Code is intended to 
have retrospective effect, and whether or not By-Law No. 1 is now in force, for in either case the result is the same. We are satisfied that both under the old law and the new an association which is dominated by the emploper is not an association in good faith, and is not therefore an association within the letter or spirit of the low. A dominated association is a sham and a froud, and as such is not entitled to certification under any circumstances.

This leads us to several other questions of low which it is just as well to dispose of here.

We begin with the proposition that although the act of dominating an association is an offence both under the Act and the Code, punishable upon summary proceeding pursuant to the Quebec Summary Convictions Act, the proceeding now before us is not a criminal or quasi-criminal matter, but on the contrary is a civil matter, and is therefore to be decided upon «the balance of probabilities», which is the rule in civil coses.

In Industrial Acceptance Corporation v. Couture, 1954 S.C.R. 34, Fouteux, J,, had this to say, at page 43 :

"... dans une cause civile où la preuve d'un crime est matérielle ou succès de l'action, la règle de preuve applicable n'est pas celle prévalant dans une cause criminelle où les sanctions de la loi pénale sont recherchées, mais celle régissant la détermination de l'action au civil."

(Also see the London Life Insurance Company v. Chase, 1963 S.C.R. 207, and the authorities therein cited.)

In Montreal Tramways Company v. Léveillée, 1933 S.C.R. 456, Lamont, J, expressed the following opinion, at page 466 :

* The general principle in accordance with which in cases like the present the sufficiency of the evidence is to be determined was stated by Lord Chancellor Loreburn in Richard Evans \& Co., Limited v. Astley (1911 A.C. 678), as foilows:

'It is, of course, impossible to lay down in words any scale or standard by which you can measure the degree of proof which will suffice to support a particular conclusion of fact. The applicant must prove his case. This does not mean that he must demonstrate his case. If the more probable conclusion is that for which he contends, and there is anything pointing to it, then there is evidence for a Court to act upon. Any conclusion short of certainty may be miscalled conjecture or surmise but Courts, iike individuals, habitually act upon a balance of probabilities. '

In Rousseau v. Bennett et al., 1955 S.C.R. 89, Taschereau, J., as he was then, had this to say, at page 92 :

"L'Honorable Juge de première instance a jugé suivant la balance des probalilités, ce qui est la preuve requise en matière civile, et je crois que le jugement de la Cour d'Appel est erroné en droit quand cette dernière conclut qu'il $n^{\prime} y$ a pas de présomption tellement forte qu'elle exclut toute autre possibilité. Ce n'est pas ce que la loi requiert. II y a une distinction fondamentale qu'il fout faire entre le droit criminel et le droit civil. En matière criminelle, la Couronne doit toujours prouver la culpabilité de l'accusé au-delà d'un doute raisonnable. En matière civile, la balance des probabilités est le facteur décisif. Comme le disait M. le Juge Duff dans la couse de Clark v. Le Roi (1921 - 61 Can. S.C.R. 608 at 616):

'Broadly speaking, in civil proceedings the burden of proof being upon a party to establish a given allegation of fact, the party on whom the burden 
lies is not called upon to establish his allegation in a fashion so rigorous as to leave no room for doubt in the mind of the tribunal with whom the decision rests. It is generally speoking, sufficient if he has produced such a preponderance of evidence as to shew that the conclusion he seeks to establish is substantially the most probable of the possible views of the facts.'

Les tribunaux doivent souvent agir en pesant les probalilités. Pratiquement rien ne peut être mathématiquement prouvé (Jérôme v. Prudential Insurance Co. of America, 1939 - 6 Ins. L.R. 59 at 60; Richard Evans $\&$ Co. Ltd. v. Astley, 191' A.C. 674 at 678; New York Life Insurance Co. v. Schlitt 1945 S.C.R. 289 at 300; Doe D. Devine v. Wilson, 10 Moore P.C. 502 at 532). "

In Harry Mahon et al. and Dame Bessie Lang et vir, an unreported judgment of the Supreme Court of Canada, rendered on October 22nd, 1946, Rand, J., expressed the following views:

« Whether the conclusion of one fact from the existence of another is a legitimate inference or a were speculation depends in law upon its characterization in that degree of experience which the tradition of legal reasoning has adopted; and the language of Lord Wright in Grant v. Australian Knitting Mills Limited (1936) A.C. 85 at page 96 puts the matter with his customary clarity

'This, however, does not do justice either to the process of reasoning by way of probable inference which has to do so much in human affairs, or to the nature of circumstantial evidence in the law courts. Mathematical, or strict logical, demonstration is generally impossible; juries are in practice told they must act on such reasonable balance of probabilities as would suffice to determine a reasonable man to take a decision in the grave affairs of life. Pieces of evidence, each by itself insufficient, may together constitute a significant whole and justify by their combined effect a conclusion.

In the King v. Sincennes - McNaughton Line Limited, 1928 S.C.R. 84, Newcombe, J., had this to say, at page 86 :

«I think there is here a preponderance of probability which constitutes sufficient ground for the finding of the learned trial judge.

In Cooper v. Slade, Willes J., refers to the proposition as elementary that in civil coses the preponderance of probability may constitute sufficient ground for a verdict, and he says that, so long since as the 14th of Elizabeth, Chief Dyer and a majority of the other Justices of the common Pleas laid it down that, when the parties are at issue the Justices may, if the matter be doubtful, found their verdict upon that which appears the most probable, and by the some reason that which is most probable shall be good evidence

Newis v. Lark. I see no reason to doubt that the present case should be governed by that rule, and the appeal therefore fails.

(Also see Jerome v. Anderson et al. 1964 S.C.R. 291, at 299.)

This leads us to the question of the evidentiary value of circumstantial evidence (o matter already touched upon in some of the authorities cited), because as learned counsel for the Amalgamated admitted, and there is no doubt that this is so, his case is founded in large measure upon evidence of this kind. Nor is this to be wondered at; indeed, it would be far more cause for wonder to find much direct evidence in a case of this sort. This is so self-evident as to need no authority, but the proposition has been put so aptly by a noted American jurist that we cannot resist citing his remarks.

In the case of F.W. Woolworth Co. v. National Labor Relations Board, Circuit Court of Appeals, Second Circuit, 121 Federal Reporter 2nd series 658, Frank, Circuit Judge, speaking for the Court, had this to say, at p. 660 : 
a (3) Implicit in petitioner's argument is a basic objection to reliance upon so-called circumstantial evidence. But courts and others triers of facts, in a multitude of cases, must rely upon such evidence, i.e., inferences from testimony as to attitudes, acts and deeds; where such matters as purpose, plans, designs, motives, intent or similar matters, are involved, the use of such inference is often indispensnble. (Cf. Wigmore, Principles of Judicial Proof (1931) 7-8,30,734-743). Persons engaged in unlawful conduct seldom write letters or make public pronouncements explicitly stating their attitudes or objectives; such facts must usually be discovered by inference; the evidence does not come in package labelled, 'Use me', like the cake, bearing the words 'Eat me', which Alice found helpful in Wonderland." (Emphasis added)

Under our law, circumstantial evidence is properly know as presumptions of fact, which under Article 1242 of the Civil Code ore «left to the discretion and judgment of the Court $\$$.

The rules governing circumstantial evidence in civil cases have been ofttimes cited and reviewed and it is unnecessory to do more here than to refer briefly to several leading authorities.

In the case of Montreal Tramways Company v. Léveillée (supra), Lamont, J., had this to say, ot page 469 :

« In Jones v. G.W. Rly Co. (1930 - 47 T.L.R. 39) the House of Lords had to consider whether there was evidence on which a jury could properly find negligence on the part of the Defendant's servants which caused or contributed to the death of the husband of the first Plaintiff. In stating the principles which should govern in such a case, Lord MacMillan, at page 45, said:

\begin{abstract}
'The dividing line between conjecture and inference is often a very difficult one to drawn. A conjecture may be plausible but it is of no legal value, for its essence is that it is a mere guess. An inference in the legal sense, on the other hand, is a deduction from the evidence, and if it is a reasonable deduction it may have the validity of legal proof. The attribution of an occurence to a cause is, I take it, always a matter of inference. The cogency of a legal inference of causation may vary in degree between practical certainty and reasonable probability. Where the coincidence of cause and effect is not a matter of actual observation there is necessarily a hiatus ir the direct evidence, but this may be legitimately bridged by an inference from the facts actually observed and proved.'
\end{abstract}

An instance of a case where this Court 'bridged the hiatus' is that of Shawini-. gan Engineering Co. v. Naud (1929 Can. S.C.R. 341). It is sufficient to refer to the judgment of the Court (Duff, Mignault, Newcombe, Rinfret and Smith, JJ.) more particularly to the passage from the foot of page 344 to the end of page 345, to realize how strikingly similar the problem of the relation of cause and effect happened to be both in that case and in the present case. By article 1242 C.C. presumptions not established by law are left to the discretion and judgment of the Court. The corresponding article in the Code Napoleon (art. 1353) is to the same effect but with the limitation that the Court will admit only such presumptions as are 'graves, précises et concordantes", by which is meant presumptions in which the connection between the facts established in evidence and the fact to be proved is such that the existence of the known facts establishes by inference or deduction the fact in dispute.

Article 1242 of the Quebec Civil Code does not contain the limitation of the Code Napoleon but as a presumption to be admitted as legal proof is necessarily a deduction from proven facts, there is, perhaps, but little if any difference between the meaning to be ascribed to the two articles. See the Montreal Rolling Mills v. Corcoran (1896- 26 Con. S.C.R. 595). " 
In Casswell and Powell Duffryn Associated Collieries Limited, 1940 A.C. 152 (House of Lords), Lord Wright had this to say, at page 169:

a My Lords, the precise manner in which the accident occured cannot be ascertained as the unfortunate young man was alone when he was killed. The Court therefore is left to inference or circumstantial evidence. Inference must be carefully distinguished from conjecture or speculation. There can be no inference unless there ore objective facts from which to infer the other facts which it is sought to establish. In some cases the other facts can be inferred with as much practical certainty as if they had been actually observed. In other cases the inference does not go beyond reasonable probability. But if there ore no positive proved facts from which the inference can be made, the method of inference fails and what is left is mere speculation or conjecture.

In the present case there are, I think, certain know facts which enable some inferences to be drawn. Beyond that point the method of inference stops and what is suggested is conjecture. n

Finally, in Jerome v. Anderson et al. (supra) Cartwright, J., had this to say, at page 300 :

- I accept as accurate the statement in Wills on Circumstantial Evidence, 7 th ed., at u. 435 :

'The effect of a body of circumstantial evidence is sometimes compared to that of a chain, but the metaphor is inaccurate, since the weakest part of the chain is also its strongest.

"Such evidence is more aptly to be compared to a rope made up of many strands twisted together. The rope has strength more than sufficient to bear the stress laid upon it, though no one of the filaments of which it is composed would be sufficient for the purpose. 》

(Also see the remarks of Rand, J., in Mahon and Lang, already cited, supra.)

This, in turn, leads us directly to the meaning to be given to "domination " under our law. The term is nowhere defined, neither in the Act nor in the Code, and we therefore assume that it is to be given its ordinary meaning, for as both our statutes « deal with matters relating to the general public (they are) presumed to use words in their popular sense; uti loquitur vulgus. " (Maxwell, On the Interpretation of Statutes, 11 th Edition, page 53.)

The Oxford English Dictionary defines « to dominate» as "to bear rule over control, sway; to hove a commanding influence on; to master $n$.

The French definitions are to the same effect, as we would expect, since the term has its roots in Lotin.

Thus Quillet, Dictionnaire de la Langue Française defines "dominer » as «commander souverainement, avoir une préséance absolue, exercer de l'empire, de l'influence. »

When, then, or under what circumstances, can it be said that an association is dominated by the employer?

It is not necessary or even desirable, and indeed it would be unwise to seek to lay down an all-embracing set of rules and considerations which presume to take into account all possible cases and contingencies. Each case must naturally be judged on its own particular facts. And yet, we have found in our experience - and our decisions in the 
past reflect this experience - that certain circumstances are indicative and oft-times conclusive of employer domination. In this respect our experience parallels, that of our sister boards elsewhere, whose enabling statutes are the inspiration of our own law in this domain, or derive from common sources, and whose purposes are the same, although the languoge may somewhat differ. On this point, we note that section 20 of the Act, and section 11 of the Code which reproduced it (with some additions) are almost verbatim reproductions of Section 8 (2) of the National Labour Relations Act of 1935, popularly known as the Wagner Act), legislation enacted by the Congress of the U.S.A. and which served as a model for much of the subsequent labour law throughout the North American continent, including Canada and our own province. Section 8 (2) of the Wagner Act was drofted in the following terms:

«8. It shall be an unfair labour practice for an employer :

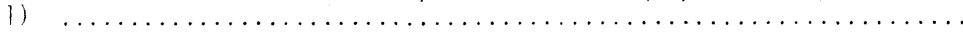

2) To dominate or interfere with the formation or administration of any labour organization or contribute financial or other support to it. "

The Labour Management Relations Act, 1947 (generally called the Taft-Hartley Act) which amended the Wagner Act, reproduced Section 8 (2), supra, as Section 8 (a) (2), with a proviso not here material. Subsequent amendments to this legislation have no relevance here.

As long ago as December 1939 the National Labour Relations Board (hereinafter called the NLRB), created under the Wagner Act, set out certain characteristics which, on the basis of its own experience, served to distinguish an employer-dominated association from a bona fide trade union. Subsequent decisions of the NLRB and of the American courts confirm the validity of these findings, and apply the principles therein contained. Needless to say, cases decided by the NLRB under its enabling legislation and by the American courts in interpreting this legislation are not binding outhorities upon us. They are none the less entitled to the greatest respect, particularly since our experience in labour law and industrial relations has followed closely, if not actually duplicated (although at a slower rate), the American experience. In particular, employer domination here has followed essentially the same pattern as employer domination in the U.S.A. and elsewhere in Canada. An analysis of our own decisions and policy in this field indicates that we have adopted and consistently followed (with very rore exceptions not material here) the principles first set out by the NLRB more than 25 years ago. We should perhaps add that we have adopted these principles as our own not " by reason of authority but by authority of reason », and because they are most "consistent with the smooth working of the system 》 which our labour law purports to regulate, and harmonize well with its basic intents and purposes.

Drawing, therefore, upon our own experience, and thot of our sister boards elsewhere, insofar as applicable, and without in any way claiming to be exhaustive, we list hereunder what we believe to be the principal characteristics of an employer-dominated association, holding the view that depending upon the circumstances, it is generally a fair conclusion that domination exists where these foctors exist in some reosonable combination. These then are the principal characteristics of an employer-dominated association: ... ......

1) It is generally formed as a so-called independent association at a time when a bona fide "outside» trade union or organization is already organizing the shop.

2) It is always supported by the employer, directly or indirectly or both. This support may be either matericl or moral, or both. The most obvious examples of materiol support 
are the free use of company premises for the holding of meetings, the use of company facilities, such as office equipment, paper and incidentals necessary for the material organization of the campaign, the payment of time to the employees during which they attended meetings on the plant premises or elsewhere, the cooperation of management and/or managerial employees to ensure that the workers have not only the time but the opportunity of joining the association and/or their being subjected to propaganda to induce them to join.

Moral support is best exemplified by management's letting it be known directly or indirectly that it looks with favour upon the independent association, that the latter is a "good " union, and for the benefit of the workers, while on the other hand the a outside * union is a bad " union .

3) Its organizers are generally without experience in labour organization and turn to management for help in all or some phases of the matter. In some cases management participates, - more or less directly, in others it merely advises the organizers where to go to get the necessary assistance, - usually the officers of another independent association which has been successfully set up and maintained in a rival plant in the same or related industry - but in all cases the organizers do not act alone.

4) It succeeds in its organization campaign with remarkable speed and ease. It usually recruits close to $100 \%$ membership within the short space of a few hours, and without a single dissenting voice.

5) It is able to obtain immediate check-off of union dues from the employer, usually followed by the rapid acceptance of a labour agreement, all this without certification, and, where there is an outside union in contention, without having to await a decision of the issues by the appropriate judicial authority. In this connection the quick and close cooperation between the employer and the association - indeed in some cases the use of the word collaboration is more appropriate than co-operation - is always ground for suspicion, particularly when there is no prior history of a bona fide employer-employee relationship, and where the employer has shown himself to be anti-union in sentiment towards an outside union trying to organize his plant.

6) It is generally a one-plant or one-company association. This is quite easy to understand, for being created or instigated to serve the purpose of the employer, it is more easily manageable, and more logical, that it be restricted to a one plant or one employer unit.

These then are the factors which we must bear in mind in deciding whether domination exists in any given cases. We hasten, however, to add several words of caution.

1) The first rule is that each case necessarily depends upon its own facts, and it is in opplying the facts in the case to the guide-lines hereinabove enunciated that a decision must be made.

2) The second rule is that the different factors hereinabove enunciated are not necessarily of equal weight or importance, and certainly are not necessarily always of the same weight or importance in different cases. Their weight depends upon the particular facts of the instance to which they are applied.

3) It remains only to say, of course, that as good faith is presumed under our law, the burden of proving domination is upon the party alleging it. On the other hand, once 
the weight of the evidence, direct or inferential, points to domination, the burden shifts, and it then falis to the association and/or the employer concerned to rebut the presumption and to prove that domination does not exist.

This having been said we turn now to the evidence before us. The facts are not basically in dispute. The question is as to the inferences to be drown from the established facts The principles that apply in the premises have already been discussed.

We have already seen that the Association applied for certification immediately after the organization of the cutters by the Cutters' Union and while the latter's application was pending. Furthermore it is not disputed that the Amalgamated Meat Cutters \& Butcher Workmen of North America, the mother union and its two locals concerned are bona fide associations and "outside" unions, in the sense earlier employed by us.

As for the Association, its history goes back to 1947. At that time the employees of Lobelle, the owner of the Maisonneuve plant, organized themselves into an independent association, incorporated under the Professional Syndicates Act, (R.S.Q. 1941, chopter 142) as the Union des Employés de R. Lobelle Limitée. It then applied to the Board for certificotion and in due course received our certificote.

Sometime in 1958, MacForlane E Lefaivre took over the assets of Labelle, including the Moisonneuve plant, which it then named its Labelie division, presumably ofter the former owner. The Association then applied for, and obtained, supplementary letters patent changing its name to Union des Employés de MacFarlane Lefairre Mfg. Ltd. (division Labelle), to conform to the new state of affairs, and this is the name that the Association still bears.

Concurrently, the Association applied for a new certificate, deeming it necessary to do so, we assume, because of the judgment recently rendered by the Court of Appeal in the case of Syndicat National des Travailleurs de la Pulpe et du Papier de la Tuque Inc., v. Commission de Relations Qurrières, (1958 K.E. 1). The Association was then in contention with another trade union and we ordered a representation vote between them. The Association won the election, and on January 9th, 1959, was duly certified once more as bargaining agent for the employees of the Maisonneuve plant.

From then on, the Association negotiated collective labour agreements with the new employer, MacFarlane-Lefaivre, the last of these agreements, and the only one material here, was for a period of two years terminating December 23rd, 1962.

We come now to the Papineau plant, which is the plant directly in issue in this cose. Boucher $\mathcal{E}$ Lefaivre is, and has been, the owner and operator of this plant for some time prior to 1962. When the Cutters' Union applied for certification, on October 29th, 1962, the Papineau plant was a non-union shop; to use the well-known colloquialism in labour matters, "le champ était libre».

It is in evidence that by the end of August 1962, twelve out of the sixteen cutters in the bargaining unit had joined the Cutters' Union, and hat it did not take too long for this to come to the ears of management. In fact, by early October, if not before, the general manager of the Company was well aware that the Papineau plant cutters were organized.

On Thursday, October 11th, 1962, at the end of the day's work, three cutters were loid off. Whether these lay-offs were justified or not we do not here decide, but one thing 
is certain, all the cuters, as a group, believed these lay-offs to be reprisals for their union octivity and hence controry to low. The cutters immediately got in touch with $\mathrm{Mr}$. Aurelien Dallaire, (hereinafter called Dallaire), the local business representative and agent of the Cutters' Union, who then telephoned Mr. Louis Rivard, (hereinafter called Rivard), the production manager of the Company at the Papineou plant. Dallaire identified himself, and told Rivord that he was outhorized to speak for all the cutters in the group, and asked for the immediate reinstotement of the three among them who had been laid off that way. After some discussion, a meeting was orranged for the following morning, Friday, October 12th. That morning, the cutters did not report for work; instead, they came to the plant with Dallaire in order to attend he meeting that had been arranged on their behalf. At this meeting, Dalloire told Rivard that all the cutters were members of the Cutters' Union, to which Rivard replied that he was well aware of the fact and had known it for some time. Dealing with the lay-offs, Rivard denied that they were connected in any way with the union activity of the group, stating that they were due solely to lack of work. The cutters then advised Rivard that they would all stay away from work until the three cutters were reinstated. Rivord undertook to take the matter up with Mr. René Boucher, (hereinafter called Boucher) the a grand patron», and general manager of the Company, who was not in the Popineau plant of the time, stating that he would communicate with Dallaire as soon as he had some news. The meeting broke up on that note, and the cutters and Dallaire lefs the plant.

The cutters did not work that day, nor did they return to the plont premises until the following Monday, October 15th.

On Friday, at 5.00 p.m., Rivard, true to his word, called Dallaire, and asked him to tell the cutters to come in on Monday morning, for a further meeting to discuss their return to work.

It is necessary at this point to turn back the clock a short while. At about the same time that Rivard was meeting with Dallaire and the cutters on Friday morning, the 12th, Boucher was meeting with the president and two other officers of the Association. This meeting took place in Boucher's office in the Maisonneuve plant, and it is significant that it is the first occasion on which Boucher, or any other member of management of the Company had any dealings with the Association, or any of its officers. The Association contends that it initiated this meeting for the purpose of asking Boucher's permission to organize the employees of the Papineou plant, a seemingly logical step since it was already certified in the Maisonneuve plant recently token over by the Company. We do not accept this contention, and we find the evidence on this point not worthy of credit. We are satisfied that the meeting between Boucher and the officers of the Association was initiated by Boucher $\&$ Lefaivre, in order to invite the Association to organize its employees in the Popineau plant, as a means of frustrating the Cutters'. Union from obtaining a foothold in the shop. Be that as it may, there is no doubt, and indeed it is admitted, that on that day, Friday, the 12 th, in the late morning or early afternoon, the three officers of the Association drove with Boucher in Boucher's automobile from the Moisonneuve plant to the Papineau plant, in order to organize the employees of that shop. Having arrived, they arranged to meet with several senior employees of the Papineau plant (hereinafter called the Papineau orgonizers) to obtoin their direct and immediate help in the compaign. The Papineau orgonizers were chosen from the different departments in the plant. (There was of course, no one from the cutting department as all the cutters had walked off the job.) Permission was then requested from Rivard and obtained, to hold a general meeting of all the employees for that very afternoon. 
At 4.00 p.m. that day, a mass meeting of the total work force was held in the fitting deportment, on the 3rd floor of the plant. Immediately prior to the meeting the Papineau organizers went through the shop, department by department, telling the employees (who were all at work) to stop working, and where necessary to stop their machines, and to go to the meeting that has been called. This was done in the presence of the foreman of the department, and of the other supervisory employees, and as we have already indicated, was carried out with the full knowledge and permission of manogement. Indeed, it could not hove been done otherwise. It is in evidence that the employees were taken by surprise, and there was some small confusion and anxiety on their part, for they had no prior knowledge of the meeting, nor of its purpose. Those who wanted to know what was going on were given little, if any, information but the impression was clear that it was the wish of monogement that they attend.

The effect was an absolute and total shut down of production during the time of the meeting, which lasted for approximately one hour. All employees who were then in the plant were present, about 150 persons in all. The meeting was addressed by only one speaker, Mr. Roméo Huard, (hereinofter called Huard) one of the Papineau organizers and a long time employee of Boucher $G$ Lefoivre. His address was short and to the point. He told them that he spoke on behalf of the Association, that the Association was the certified agent for the employees of the Maisonneuve plant and had a collective labour agreement covering them which it had signed with MacFarlane \& Lefaivre (the former owner), that the agreement conferred certain benefits upon the employees, and that if the workers in the Papineau plant joined the Association, the latter would negotiate a similar agreement with Boucher $\&$ Lefaivre to cover them. Huard made the proposition attractive, promising better working conditions, bonuses and other benefits.

In the meantime, application cords and check-off forms hod been prepared in great haste. In foct, it would appear that the ink was barely dry on most of them whey they were brought up to the meeting. These cards and forms were prepared on the premises of the Papineau plant, either by management or with its active cooperation and assistance. The testimony of the officers of the Associotion who gave evidence to the contrary is not worthy of credit, and is rejected.

Huard's efforts were crowned with remarkable, not to soy ostonishing, success. In less than one hour almost everyone at the meeting signed application cards to join the Association, together with check-off forms authorizing the Company to deduct their monthly dues from their pay, and at the same time paid the $\$ 1.00$ initiation fee required by the constitution of the Association.

Several employees who were either in doubt or somewhat confused by the speed with which events were moving, asked for advice from their foreladies, and were quickly assured that the Association was a une bonne chose ». All in all, the Association's campciign, if we may call it that - we are somewhat tempted to use the word ablitzkrieg », although not in the pejorative sense - was an overwhelming success. Every member of the work force in the plant, except the cutters who, as we have seen, had stayed away from work, and several other employees who were absent for other reasons, joined the Association during the course of the meeting. It would also appear from the evidence that the time lost by the employees during the course of the meeting was not deducted from their wages.

It is important to recall that the meeting was held at a time when, to the knowledge of manogement, there were no cutters in the plant, nor any likelihood that there would be in view of the circumstances. 
The success of the Association's campaign did not, however, settle the question of the cutters, a question which was still acute. It will be recalled that Rivard telephoned Dallaire on Friday, the 12th at 5.00 p.m., and arranged for a meeting the following Monday, the 15 th. On that day, Dallaire and the cutters met with management in the plant. Boucher was present at the meeting and made it abundantly clear that he looked with considerable disfavour upon the Cutters' Union, and its entry into the plant. While Boucher ostensibly paid lip service to the principle of freedom of association, there is no doubt that the purpose of the meeting (as that of subsequent meetings) was to induce the cutters to leave the Cutters' Union and to join the Association which was now ensconced in the plant. Indeed, Boucher made it clear, as did Rivard, that everything would be settled, and all would be well if the cutters only abandoned their Union, and joined the ranks of the Association.

However the cutters stood firm, and said so in no uncertain terms. It is then that Boucher stated in the following or similar terms: « Restez avec votre union, si vous voulez; moi j'ai la mienne; moi je suis le patron; il faut que je me protège $₫$. The testimony of the several witnesses colled on behalf of the Amalgamated on this point is uncontradicted. Boucher did not give evidence before us.

Although the cutters did not join the Associotion, they did return to work shortly thereafter, and matters remained in suspense for the time being.

Sometime in the middle of December of that year, a further meeting was held between the parties in an effort to bring the cutters into the Association. By that time, of course, the Association had already applied to be certified as bargaining agent for all production employees, hence including the cutters, in the plant. At this meeting, there were some veiled hints that as Christmas bonuses were a matter of discretion with management they might be withheld from the cutters if they remained adamant, but the cutters remained loyal to their Union and refused to join the Association. In fairness to the employer, it should be stated that the cutters received their Chrismas bonuses and all other subsequent benefit which were poid to the work force without discrimination under the new collective labour agreement which the Company signed with the Association.

It remains only to recall that sometime during the latter part of 1963 the Amalgamated organized the total production force of the Papineau plant and on January 17th, 1964, applied for certification as their bargaining agent; at the same time the Cutters' Union discontinued its original application on behalf of the cutters only.

These then are the material facts. Has the Amalgamated made out its case against the Association? We think that it has. After consideration of the evidence in its entirely, and having regard to the authorities cited earlier, we ore satisfied that upon $\alpha$ the balance of probabilities $»$, the contestation of the Amalgamated is well founded. The weight of the evidence is clearly to the effect that at all times material to the present issues, and in particular at the time of the organization of the employees in the Papineau plant, the Association was dominated by the employer, and not an association in good faith within the meaning of our law. Under the circumstances the application of the Associotion is unfounded, and must be dismissed.

There is no need to recapitulate the facts as we have already set them down in more than sufficient detail. It is sufficient to say that when the Association organized the employees and applied for certification, it lacked that essential characteristic of freedom of action and independence of spirit without which an association cannot be a true 
association of employees within the meaning of our law. The manner in which the decision to organize was made; the persons involved in that decision; the circumstances surrounding the original meeting with management; the co-operation by management, indeed the eagerness to cooperate; the recruiting on the plant premises during working hours; the haste with which the campaign was undertaken and completed; the quick consent by management of the voluntary check-off; the general air of satisfaction and content which exuded from the Company and from its senior supervisory employees when the campaign was lounched and succeeded; the overwhelming success of the compoign; all these things lead us to the conclusion that the purpose of the Associotion wos not the defence and development of the economic, social and moral interests of its members, but rather assistance to the employer in preventing a bona fide association from entering the plant. All in all, the Associotion had no independence of oction; it permitted itself to be used and was used by management os a tool to prevent the workers from exercising their free right of association, a right which is theirs and their alone: An ossociation which lends itself to such a monoeuver, and which cooperates in such an unlowful purpose is not, and cannot be, an association within the meaning of our low. It is not in the public interest - indeed it is clearly controry to the public interest - that on ossociation that participates in on attempt to strike at the freedom of associotion of a group of workers be then recognized as their bargaining agent. Nor is the strength of this conclusion impaired because shortly thereafter the Association negotiated a collective agreement with the Company on behalf of he employees concerned. Indeed the consent of the Company to sign such an agreernent before the Association was certified, and at a time when it was opposed and alleged to be dominated, tends to confirm the domination by the employer and the lack of good faith on the part of the Association. Nor can it be said that the relationship between the Associcition and the Company and the speedy conclusion of a collective labour agreement was merely evidence of good and harmonious employer-employee relations. There never was any relationship of any kind between Boucher $\mathcal{G}$ Lefaivre and the Association prior to October 12th, 1962, when management invited the Association to organize its employees in its Papineau plant. Boucher $E$ Lefaivre had never dealt with the Association prior to that time, and in fact none of the members of the Associotion had ever spoken to anybody in management before then.

Whatever the past history of the Association may hove been with Labelle and MacFarlane $E$ Lefaivre, the former employers, and whether it was or was not a free and independent association vis-d-vis them, the fact remains that it had no bargaining history, no prior experience of any kind, with Boucher $\xi$ Lefoivre, the new employer.

It is not, therefore, a case of the employer simply preferring a union he knew to one he did not know. The Association was new and unknown to the Company and if the Company took the Associotion to its bosom so quickly, it was becouse it had reasonable grounds to believe and expect that it would do its bidding and be a creature of its will. All the circumstances point to domination. The Association is tainted by it and so is its application for certification.

For the foregoing reasons, we are to dismiss the said applicotion, and there will be judgment accordingly.

\section{LE CERTIFICAT CONJOINT D'ACCREDITATION}

This leoves us with the opplication of the Amalgamated. The only argument raised against this application is contained in a lettre from learned counsel for the Association 
dated October 16th, 1964, (and received by us on October 19th, 1964) from which we cite the following portion that is moterial:

«Les locaux 102 et 108 (sic) de deux associations différentes se sont associées pour demander la reconnaissance syndicale. L'orticle 4 de la loi des relations ouvrières le permettait.

Je soumets respectueusement que l'orticle 20 du code du travail ne le permet plus et qu'ò ce titre, la demande de lo partie adverse devrait être rejetée. (Je m'inspire de l'article d'un spécioliste en lo matière, le R.P. Gérord Hébert, s.j. - lo Revue Relations, octobre 1964, p. 297 à la note 1 - ).

The note to which counsel refers is drafted in the following terms:

* A propos de la tendance à fovoriser des unités de négociotion restreintes nous avons omis de signaler, dans le premier article, l'observation suivante, Lo Loi des relations ouvrières disait explicitement que 'plusieurs associations de salariés (pouvaient) s'unir pour former cette majorité (majorité absolue des salariés dans l'unité de négociation) et nommer des représentants pour fin de négociation collective' (L.R.O., art. 4). Le Code n'o pas retenu cette précision; il dit simplement: 'A droit à l'occréditation l'ossociation de saloriés groupant la majorité absolue des employés d'un employeur.' (Code, art. 20) Selon les définitions du Code lui-même, on doit entendre par 'association de salariés' 'un groupement de salariés constitué en syndicat professionnel, union, froternité ou autrement' (Code, ort. 1, a). Reste ò savoir quel sens it faut donner à ce dernier mot. Si on l'éclaire par ceux qui précèdent, it faudrait l'entendre d'un syndicot individuel formé sous un autre nom que ceux qu'indique le texte. De plus, l'emploi du singulier à l'orticle 20 semble confirmer cette interprétation. Quoi qu'il en soit, à l'encontre de la Loi des relations ouvrières, rien dans le Code ne fait allusion à une unité de négociation qui engloberait plusieurs associations de salariés.

Our own view is that counsel for the Association reads far more into the citation than the learned author intended to say; witness the guarded language employed in the final sentence, which rather tends to leave the question open. But assuming that the outhor, indeed, is authority for the proposition urged upon us, and, in any event, dealing with the proposition as a submission on the part of the Association, we are contrained to say, with respect, that we do not agree. Such a construction, in our judgment, takes far too narrow a view of the question and misconceives the legislative intent.

While we are inclined to share the view that \& autrement " (otherwire $)$ in the definition of association of employees " should be comprehended in the restricted sense required by the ejusdem generis doctrine, we do not believe that onything really turns upon this point. The real issue, in our opinion, lies in the proper construction of association of employees in the context of the statute, as a whole, considering its basic scope, intent and purposes, and upon these considerations we believe the stand of the Association to be untenable.

The rules of statutory construction and the authorities upon which we rely for the conclusion to which we have come ore the following

The Interpretation Act, R.S.Q. 1941, c. I:

a 2. This act shall apply to every statute of the Legistature of this Province, unless and in so far os such application be inconsistent with the object, the context or any of the provisions of such statute.

41. Every provision of a statute, whether such provision be mandatory, prohibitive or penal, shall be deemed to have for its object the remedying of some evil or the promotion of some good 
Such statute shall receive such fair, large and liberal construction as will ensure the attainment of its object and the carrying out of its provisions, according to their true intent. meaning and spirit.

a 54. The singular number shall extend to more than one person or more than one thing of the same sort, whenever the context admits of such extension.

(Also see Brooks v. Parlick, 1964 S.C.R. 108 at 113.)

Canada Sugar Refining Co. Ltd. v. Queen (1898) A.C. 735 (Privy Council)
Per Lord Davey, at page 741:-

- Every clause of a statute should be construed with reference to the context and the other clauses of the Act, so as, so far as possible, to make a consistent enactment of the whole statute or series of statutes relating to the subject-matter.

Maxwell (op. cit.) at page 28 :

* Passing from the external history of the statute to its contents, it is an elementary rule that construction is to be made of all the parts together, and not of one part only by itself. Incivile est nisi tota lege perspecta una aliqua particula ejus proposita judicare vel respondere. Such a survey is often indispensable, even when the words are the plainest; for the true meaning of any passage is that which (being permissible) best hormonises with the subject and with every other passage of the statute. 'It is, of course, impossible to construe particular words in a statute without reference to their context and to the whole tenor of the Act'..

(Also see Brooks v. Povlick, 1964 S.C.R. 108 at 113.)

Looking at the Code as a whole it is clear that it was enacted for the purpose of providing the machinery for collective bargaining as a means of achieving and maintaining industrial peace. Referring to the Act (which the Code replaces) Hyde, J., had this to soy, in Price Brothers and Company L.d. v. Letarte et al. (1953 K.B. 307, at page 312):

« The scope and object of this statute is without question to provide the machinery for securing agreements between employers or groups of employers and their employees or group of employees. The scheme of the Act is to provide for the selection of a bargaining representative of the employees, the negotiation of the agreement, the arbitration of disputes arising both in the negotiation of the agreement and out of the operation of an agreement already negotiated. 2

Under our law the certification process is the first step towards collective bargaining. Where, therefore, two constructions are possible, we must choose the one that encourages the process and enlarges its scope, rather that the one that discourages and curtails it. This is all the more apparent when we consider the way in which the Code has enlarged upon the Act and broadened the area of certification. In doing so the legislator has given further evidence, if need be, of his intention to widen rather than narrow the base of trade union activity. It is inconceivable to us that, with this in mind, he intended to make the process more dfficult, requiring in many cases serious, almost radical, changes in accepted internal trade union organization and practice.

Having regard to the foregoing, we are satisfied that upon the proper construction of the Code as a whole, two or more groups of employees may join together to form an * association of employees w within the meaning of the Code, and that if they otherwise comply with our requirements for certification, they are entitled to a certificate as bargaining agent for the groups concerned. 
Any other view is untenable; it would lead us to the conclusion that, contrary to the avowed intention of the legislator to encourage collective bargaining, * the accepted postulate of industrial peace $"$, the Code intends to strike a near-fatal blow to the great many trade unions which, while organized by tradition on a craft or group basis, none the less organize on an industrial or all-employee basis, when appropriate, by joint applications made by two or more of their locals, acting together. To conclude that the legislator intended such a drastic and radical change from the existing law - a law which works and harmonizes best with the existing social structures in the system which the law was designed to regulate - would require a far more clear and explicit enactment than that which the Association contends may be inferred from the failure to reproduce in the Code the second paragraph of Article 4 of the Act.

Maxwell (op. cit.) has this to say, at page 78 :

« Before adopting any proposed construction of a passage susceptible of more than one meaning, it is important to consider the effects or consequences which would result from it, for they often point out the real meaning of the words. There are certain objects which the legislature is presumed not to intend, and a construction which would lead to any of them is therefore to be avoided. It is not unfrequently necessary, therefore, to limit the effect of the words contained in an enactment (especially general words), and sometimes to depart, not only from their primary and literal meaning, but also from the rules of grammatical construction in cases where it seems highly improbable that the words in their wide primary or grammatical meaning actually express the real intention of the legislature. It is regarded as more reasonable to hold that the legislature expressed its intention in a slovenly manner, than that a meaning should be given to them which could not have been intended.

\section{Presumption against Implicit Alteration of Law.}

One of these presumptions is that the legislature does not intend to make any substantial alteration in the law beyond what it explicitly declares, either in expressed terms or by clear implication, or, in other words, beyond the immediate scope and object of the statute. In all general matters outside those limits the low remains undisturbed. It is in the last degree improbable that the legislature would overthrow fundamental principles, infringe rights, or depart from the general system of law, without expressing its intention with irresistible clearness, and to give any such effect to general words, simply because they have a meaning that would lead thereto when used in either their widest, their usual or their natural sense, would be to give them a meaning other than that which was actually intented. General words and phrases, therefore, however wide and comprehensive they may be in their literal sense, must, usually, be construed as being limited to the actual objects of the Act. It would be 'perfectly monstrous' to construe the general words of the Act so as to alter the previous policy of the law. $\infty$

We have no doubt that the deletion of the second paragraph of Section 4 of the Act, and the failure to reproduce it in the Code was not for the purpose of removing a right which existed under the Act, and which the legislator did not wish to retain under the Code; the deletion was merely the elimination of surplus language. The paragroph was unnecessary even in the Act; and all the more so in the Code. Its elimination was another instance of legislative surgery upon useless language, to eliminate its possible misconstruction in the future.

In Shannon Realties v. Ville de St. Michel, 1924 A.C. 185, Lord Shaw had this to say, at page 192:

«Where alternative constructions are equally open, that alternative is to be chosen which will be consistent with the smooth working of the system which the statute purports to be regulating; and that alternative is to be rejected 
which will introduce uncertainty, friction or confusion into the working of the system. $n$

This is a further reoson, if one be needed, for rejecting the construction urged upon by the Association.

On the whole, therefore, and for the foregoing reosons, the orgument of the Association foils.

Having come to this conclusion it becomes unnecessary to decide whether the argument foils in any event becouse whatever retrospective effect, if any, the transitory provisions of the Code are intended to have, they do not in this instonce operate to deprive the Amalgomated of its rights to certification acquired under he Act. In our view, whether we apply the Act or the Code to the determination of the issues herein, and whether the tronsitory provisions of the Code ore retrospective or not, the Amalgamated is entitled to succeed.

After coreful consideration of the evidence, including the documents of record, the reports of our inspectors, and of the file in its entirety, we find that:

1) The bargaining unit sought by the Amalgamated as herein earlier described is an appropriote unit in all the circumstances of the cose.

2. The Amalgamated is an association of employees within the meaning of our law

3) The Amalgamated comprises among its members the absolute majority af the employees in the said borgaining unit.

4) The Amalgamated has complied with all legal requirements for certification as the bargaining agent for the employees in the soid unit.

In the circumstances, the Amalgamated is entitled to certification, and a certificate will therefore issue.

CONSIDERING that at all times material to the present issues the Association herein was dominated by the Company;

CONSIDERING that, insofar as the present instance is concerned, the Association was not and is not an association of employees within the meaning of our law;

CONSIDERING, therefore, that the application for certification made herein by the Association is unfounded, and must be dismissed;

CONSIDERING, on the other hand, that the Amalgarnated is an association of employees within the meaning of our law, and has complied with all legal requirements for certification as bargaining agent for the employees hereinafter described:

* Les employés de la production de la chaussure payés à l'heure et à la pièce in the plant in issue.

CONSIDERING that the application for certification filed by the Amalgamated herein is well founded, and must be granted.

FOR THE FOREGOING REASONS, we do hereby:

1) REJECT, for all legal purposes, the application for certification filed herein by the Union des Employés de MacFarlane Lefaivre Mfg. Ltd. (Division Labelle), on the 13th of 
November, 1962, to be certified as the bargaining agent for "tous les employés travaillant à lo fabrication de la chaussure, ò la main ou à la machine $\gg$ in the employ of Boucher $\mathcal{G}$ Lefoivre Limited, ot its plant of 1740 Papineau Street, Montreal;

2) RECOGNIZE the Union des Employés du Cuir de Montréal, Local L-102, Union des Tailleurs en Chaussures, Local 118 LF, locoux de l'Amalgamated Meat Cutters and Eutchers Workmen of North Americo AFC CIO CTC, les deux locoux conjointement, as the bargaining agent of the following group of employees, namely:

* les employés de la production de la choussure payés à l'heure et à la pièce »

in the employ of Boucher $\mathcal{G}$ Lefoivre Limited, at its plant at 1740 Papineau Street, Montreal, Quebec, and we do hereby issue in favour of the said Union des Employés du Cuir de Montréal, Lacal L-102, Union des Tailleurs en Choussure, Local 118 LF, locaux de I'Amalgomoted Meot Cutters and Butcher Workmen of North Americo AFL ClO CTC, les deux locoux conjointement, a certification of recognition in regard to the said group of employees;

The whole under the provisions of law provided.

\section{ARBITRAGE - Tâches - Reclassification à cause de nouvel équipement.}

Un tribunal majoritaire (l'arbitre syndical étant dissident) décide qu'un employeur n'est pas tenu de créer une occupotion nouvelle lorsqu'il fait racquisition de machines nourelles qui n'entrainent pas de changement dans les éléments essentiels d'une tôche.

\section{Le simple fait d'inconvénients plus grands entourant l'utilisation de ces machines ne constitue pas une accupation nouvelle ou un \& changement de tôche ou sens de la conrention collective, mais justifie un taux de salaire plus élevé à ceux qui l'utilisent. ${ }^{1}$}

Au mois de décembre 1963, l'employeur a acheté une nouvelle machine à souder dite machine innershield». Il s'agit d'une machine qui emploie un filament continu pour fin de soudure, lequel filament se déroule de lui-même et d'une façon outomatique aussi longtemps que l'employé appuie sur une a gachette , faisant partie de la poignée servant à tenir et à contrôler la machine.

Cette machine, utilisant un filament continu se déroulant au fur et à mesure de l'opération de soudure, est différente des machines ò souder ordinaires, lesquelles utilisent des tiges (rods) de métal qu'il faut changer une fois chaque tige épuisée. Elle permet donc, entre outres coractéristiques, une opération plus rapide et impliquant moins de perte de motériel à souder.

Les ploignants, tous des soudeurs classés «A», ont travaillé sur cette machine (la seule de son genre chez l'employeur) durant quelques mois, à tour de rôle, selon les besoins

(1) Forono Limitée et le Syndicat cotholique des employés de Fonderies de Plessisville Inc.; Me Jean-Réal Cardin, président, $M$. Denis Germain, arbitre patronal, $M$. Raymond Parent, arbitre syndical (dissident); Québec 18 décembre 1964. 